\title{
The Relationship Between Normalized Difference Vegetation Index with Phytochemical Content of Pasak Bumi
}

\author{
Ahmad Jauhari ${ }^{1,2, *}$ Yuniarti $^{1}$ Eko Suhartono ${ }^{2,3}$ Rahman Noor $^{1}$ \\ ${ }^{1}$ Faculty Forestry, University Lambung Mangkurat, Banjarbaru, Kalimantan Selatan, Indonesia \\ ${ }^{2}$ Faculty Medical, University Lambung Mangkurat, Kalimantan Selatan, Banjarbaru, Indonesia. \\ ${ }^{3}$ Center of Excellent Research Consortium for Sustainable Forest Management, Banjar Baru, Indonesia \\ *Corresponding author. Email: zihrin646@gmail.com
}

\begin{abstract}
Understanding of the post geothermal plant growing conditions based on digital values on satellite images of Normalized Difference Vegetation Index (NDVI) relative to the amount of the phytochemical content of the plant may provide benefits for cultivation management in its growing place. The purpose of this research is to predict the correlation between NDVI and the flavonoid-alkaloid value of pasakbumi. This research was conducted at Forest Education of Lambung Mangkurat University, South Kalimantan Province. Data analysis methods used are GIS analysis (satellite image interpretation, NDVI, and geoprocessing) and analysis of alkaloid and flavonoid values. This study confirmed the correlation between NDVI $(\mathrm{x})$ and flavonoid $(\mathrm{y})$ with the equation $\mathrm{y}=-0.90+12.41 \mathrm{x}(\mathrm{R} 2=0,444$ or $\mathrm{r}$ value $=0.667$ ), which meant that the content of flavonoid in pasakbumi tends to decrease with the higher amount of NDVI. The correlation between NDVI and alkaloid was $y=2.767+9.822 x(R 2=0.570$ or $r=0.754)$, which meant that the content of alkaloids tends to increase with the denser pasak bumi coverage.
\end{abstract}

Keywords: NDVI, Phytochemical, Alkaloid, Pasakbumi

\section{INTRODUCTION}

Indonesia is a country with abundant natural resources, almost all kinds of plants can grow in this country. Mostly exploited by ancestors to treat various diseases [1]. Indonesia's tropical forest area has the second-highest biodiversity after Brazil. Indonesia has more than 20,000 types of medicinal plants. However, only 1,000 species have been recorded, while only about 300 types have been used for traditional medicine [2].

South Kalimantan has a high biodiversity, one of which is pasak bumi (Eurycoma longifolia jack). A study conducted by the Forest Research Institute of Malaysia (FRIM) states that pasak bumi is rich in Superoxide Dismutase (SOD). SOD is an antioxidant enzyme that captures free radicals. The pasak bumi plant has eight alkaloids found on the root of the pasak bumi, one of which 9-methoxycanthin-6-one which can inhibit the growth of cancer cells [2], there is also a flavonoid compound with $6.1 \pm 0.8 \mathrm{QE} \mu \mathrm{g} / \mathrm{mL}$ [3]. In general, these medicinal plants have been scarce. The scarcity of medicinal plants is caused by a) habitat destruction caused by forest exploitation; b) slow regeneration power for perennial crop species; and c) lack of attention to the cultivation of medicinal plants in the relatively rare species [3].

A growing site condition that can affect the potential phytochemical content of the plant is the density of the forest stand. To facilitate rapid assessment of standing densities can be done through satellite image interpretation. The LANDSAT image is a satellite image that can be used to assess the greenish index. NDVI (Normalized Differences Vegetation Index) is one of the most widely used approaches in assessing the greenish index. Lillesand and Kiefer, 1997 states that the greenish vegetation index is a mathematical combination between the RED band (band 4) and the NIR band (band 5) has been used to identify the presence and condition of vegetation. The purpose of this research is to know the condition of place to grow by using NDVI Class relation with the potency of Flavonoid and Alkaloid content from pasak bumi plant. 


\section{MATERIALS AND METHODS}

\subsection{Study Area}

This research was conducted at Forest Area with Special Purpose (KHDTK) Faculty of Forestry University Lambung Mangkurat (UNLAM) and Laboratory Faculty of Medical UNLAM. The location of the sampling is presented in Figure 1 below.

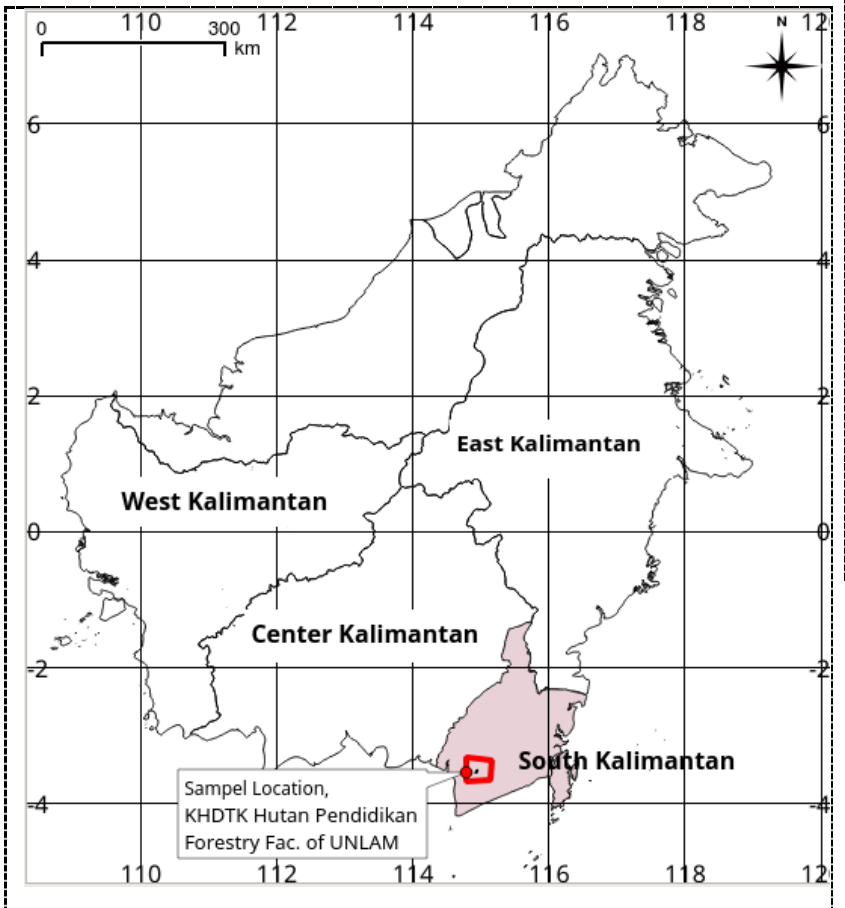

Figure 1. Location Map of Location Research

This research is quantitative descriptive research. The main ingredients used in this study were the pasak bumi Plants and the NDVI digital values of the LANDSAT-8 image. The method of analysis used in this study is the regression method. The regression variables measured were NDVI values, Flavonoid potential, and Alkaloids. Stages Implementation of the research is started by processing LANDSAT-8 image into NDVI value, then put the example in each class of NDVI, after that do sampling plant of Pasak Bumi in each class of NDVI, followed by bringing and test sample Pasak Bumi plant in the laboratory, then process and analyze the data to get the value of the relationship between the potential of Flavonoid and Alkaloid with the value of NDVI, ending by making a report of research results.

\section{RESULTS AND DISCUSSION}

\subsection{NDVI Classes}

Based on the result of LANDSAT-8 image interpretation at KHDTK area of Faculty of Forestry
UNLAM using NDVI method gives 5 class NDVI result. The results of NDVI analysis are presented in Figure 1 below.

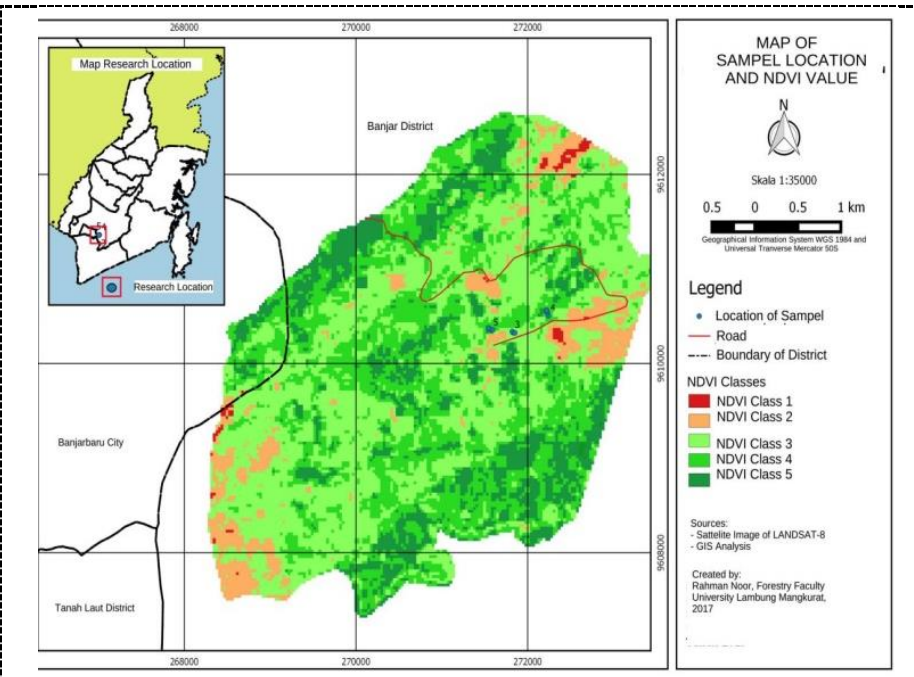

Figure 2. Map of NDVI Classes and Location of Sample in Research Area

Figure 2 shows the NDVI class distribution map and the location of sampling of the pasak bumi plant. Based on LANDSAT-8 satellite image interpretation results there are 5 class NDVI. Of these five classes, the sampling sites are NDVI 3, 4, and 5. This is because in the NDVI 3-5 class there is still a pasak bumi plant. The NDVI 3-5 class is scattered almost on all research sites. Determination of sample location is placed in an easily accessible area. At each sample location, sampling is taken 3 pasak bumi plants.

\subsection{Flavonoids and Alkaloids}

Based on the results of laboratory tests on the flavonoid and alkaloid content of the pasak bumi root of the various NDVI classes are presented in Table 1.

Table 1 shows the values of Flavonoid and Alkaloid content at various levels of the NDVI class. In the table seen Flavonoid content tends to decrease with increasing the value of NDVI class or greenish or the density of stands. This means that the Flavonoid content tends to decrease with increasingly tight stands. Meanwhile, Alkaloids content tends to increase with increasing values of NDVI or greenish indices or increasingly density of stands. 
Table 1. Recapitulation of flavonoid content and alkaloid earth root pasum (Eurycoma longifolia Jack)

\begin{tabular}{|c|c|c|c|}
\hline \multirow{3}{*}{$\begin{array}{l}\text { NDVI } \\
\text { classes }\end{array}$} & \multirow{3}{*}{ Replication } & \multicolumn{2}{|c|}{$\begin{array}{c}\text { Root of pasak bumi } \\
\text { (Eurycoma longifolia Jack) }\end{array}$} \\
\hline & & Level of & Level of \\
\hline & & Flavonoid (\%) & Alkaloid (\%) \\
\hline \multirow{5}{*}{3} & 1 & 10.076 & 15.440 \\
\hline & 2 & 10.580 & 18.640 \\
\hline & 3 & 9.152 & 21.400 \\
\hline & Average & 9.936 & 18.493 \\
\hline & Std. dev. & 0.591 & 2.435 \\
\hline \multirow{5}{*}{4} & 1 & 8.480 & 22.840 \\
\hline & 2 & 7.964 & 19.280 \\
\hline & 3 & 8.628 & 18.320 \\
\hline & Average & 8.357 & 20.147 \\
\hline & Std. dev. & 0.285 & 1.944 \\
\hline \multirow{5}{*}{5} & 1 & 9.512 & 22.600 \\
\hline & 2 & 6.732 & 24.680 \\
\hline & 3 & 8.164 & 24.800 \\
\hline & Average & 8.136 & 24.027 \\
\hline & Std. dev. & 1.135 & 1.010 \\
\hline $\begin{array}{l}\text { Source: } \\
\text { Laborato }\end{array}$ & $\begin{array}{l}\text { Result An } \\
m\end{array}$ & is of $\mathrm{Me}$ & cal Faculty \\
\hline
\end{tabular}

\subsection{Relationship between NDVI Value with Flavonoids and Alkaloids}

Based on table 1 above can be made a graph of the regression relationship between NDVI value with Flavonoid and Alkaloid content. The graph of the relationship can be seen in Figure 2 below.

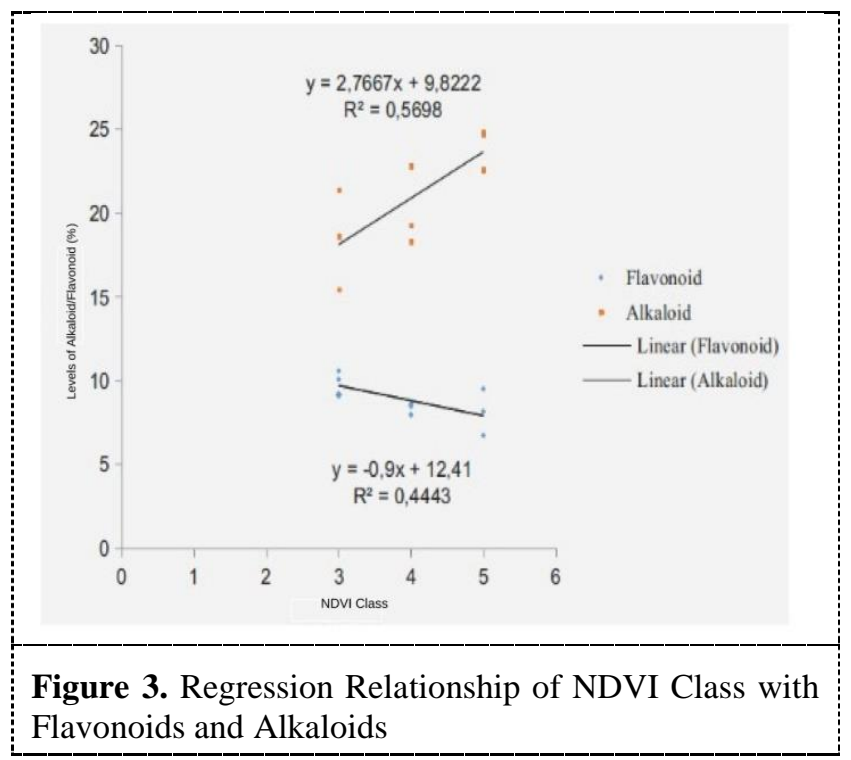

Figure 3 shows the regression relationship between NDVI class and Flavonoid and Alkaloids. Equation of regression relationship of NDVI and Flavonoid value is $\mathrm{y}=-0.9 \mathrm{x}+12.41$ with value $\mathrm{R} 2=0.443$ or $\mathrm{r}=0.67$. Equation of regression relation of value of NDVI and Alkaloid is $\mathrm{y}=2.7667 \mathrm{x}+9.8222$ with value $\mathrm{R} 2=$ 0.5689 or $\mathrm{r}=0.75$.

\section{CONCLUSIONS}

The denser the flavonoid content tends to decrease by $0.9 \%$. The magnitude of the effect of density represented by the greenish index (NDVI class) on the decrease of Flavonoid content reaches the remaining $67 \%$ is estimated to be influenced by other factors. Salisbury (1995) says that the more often the pasak bumi plants are exposed to light, then the formation of flavonoids is increasing.

Conversely, the more dense the content of the alkaloid content tends to increase. The increase of alkaloids content reached $2.77 \%$. The effect of stand density represented by the NDVI class on Alkaloid content increase reaches 75\%. Utami and Robara, 2008 say that from identification using UV lamps, it is known that the alkaloid compound is active UV.

\section{ACKNOWLEDGMENTS}

The author would like to express sincere gratitude to the Center of Excellent Research Consortium for Sustainable Forest Management, Banjarbaru, Indonesia, which financial support for the presentation of this research.

\section{REFERENCES}

[1] S.L. Rahmawan, Isolasi dan Identifikasi Flavonoid dari Daun Dewandaru (Eugenia uniflora 1), in: http://etd.eprints.ums.ac.id/994/1/K100040231.pdf

[2] T.Q. Arief, Pengantar Metodologi Penelitian untuk Ilmu Kesehatan, Edisi 1, UNS Press, Surakarta, 2008, pp. 13-76.

[3] Djauhariya, Sukarman, Utilization of Germplasm in Natural Herbs and Cosmetics Industry, Buletin Plasma Nuftah 8(2), 2002, pp. 12-13.

[4] R.D. Boya, Effect of extract of pasak bumi root on the histological structure of liver cells of mice exposed to paracetamol, Medical School. Sebelas Maret University, 2013.

[5] E. Suhartono, E. Viani, M.A. Rahmadhan, I.S. Gultom, M.F. Rakhman, D. Indrawardhana, Total flavonoids and Antioxidant Activity of Some Selected Medicinal Plants in South Kalimantan of Indonesia, APCBEE Procedia, 4, 2012, pp. 235239. 